Studia i materiały z dziedzictwa kulturowego Torunia i regionu, t. 1: STARE I NOWE DZIEDZICTWO TORUNIA,

Toruń 2013

http://dx.doi.org/10.12775/SiMzDzKTiR_T1.2013.008

Katarzyna Daniel

(RESTAURO S.A., TORUŃ)

\title{
XV-wieczny warsztat rzemieślniczy i artystyczny budowniczych kościoła Świętojańskiego w Toruniu
}

Program prac konserwatorskich, prowadzonych w kościele Świętojańskim w latach 2010-2013 przez zespół firmy Restauro, zakładał przywrócenie świątyni szaty dekoracyjnej z drugiej połowy XV wieku. Dzięki szeroko zakrojonym badaniom odkrywkowym, poprzedzającym działania konserwatorskie, wspieranym analizą historyczną, żywiono nadzieję na odtworzenie jednolitej koncepcji architektonicznej, rzeźbiarskiej i malarskiej świątyni z czasów, w których uzyskała aktualną bryłę. Tak przyjęty kierunek działania pozwolił konserwatorom na wnikliwą analizę sposobu pracy XV-wiecznych mistrzów.

W niniejszym opracowaniu przedstawione zostały niektóre spostrzeżenia, dotyczące architektury i dekoracji głównie korpusu świątyni, na które pozwolił stopień zaawansowania prowadzonych prac i badań laboratoryjnych. Skupiono się na odkryciach dotyczących XV -wiecznej warstwy historycznej, tożsamej z bryłą wysokiego kościoła, która przetrwała do dzisiaj. Świadomość, iż wcześniejsze trzynasto- i czternastowieczne dekoracje i warsztaty rzemieślnicze były wielokrotnie omawiane powoduje, iż posłużono się nimi jedynie w celach porównawczych, traktując jako punkt wyjścia do analizy działań następców.

Kościół Świętojański od czasów tzw. drugiej świątyni, czyli od początku XIV wieku murowano cegłą o uśrednionych wymiarach 28 x 9 x $13 \mathrm{~cm}$. Cegły ułożono w wątku wendyjskim i polskim na zaprawie wapienno-piaskowej, wyciskanej i obcinanej płasko lub w daszek. Wszystkie ściany i filary drugiego kościoła wymurowano z dużą starannością, z przeznaczeniem do ekspozycji bez tynków. Odsłonięty mur ozdobiono cegłą dekorowaną zielonym szkliwem bądź czarną angobą (filary i półfilary) lub pomalowano czerwoną monochromią i bielą w sposób imitujący wątek ceglany (ściany). Ściany powyżej drugiego kościoła, wzniesione prawdopodobnie w latach 30. XV wieku¹, wymurowano równie starannie, i to mimo przeznaczenia pod tynk. Odstępstwo stanowią filary podwyższone w XV wie-

1 Inskrypcja na ścianie wschodniej datująca wznoszenie ściany ponad łukiem tęczowym: ANNO D[OMI]NI 1433. IN VIGILIA S. LAURENTII. HIC FORNIX PERFECTUS EST. ANNO D[OMI]NI 1730. TEMPLUM HOC RENOVATUM EST (Roku pańskiego 1433 w wigilię św. Wawrzyńca ten łuk został wykonany. Roku pańskiego 1730 świątynia ta została odnowiona. Tłum.: I. Brzostowska). 
ku, wybudowane jakby w pośpiechu, z zaprawą roztartą na lico cegieł. Świadomość tynkowania filarów, które wymuszone było potrzebą estetycznego uporządkowania wnętrza, w tym przypadku skłoniła murarzy do mniej precyzyjnej pracy (il. 1).

Niestaranność budowlana murarzy zatrudnionych do budowy tzw. wysokiego kościoła widoczna jest również w przypadku żeber sklepiennych. Podniesienie sklepień miało miejsce w drugiej połowie XV wieku, o czym informuje inskrypcja na zachodniej ścianie nawy północnej ${ }^{2}$. Żebra „wysokiej świątyni” wielokrotnie zdają się "gubić” geometrię; miejsca ich łączenia oraz klucze sklepienne wykonane zostały w sposób niechlujny, daleko odbiegający od standardów wyznaczonych przez budowniczych XIV-wiecznych, których efekty pracy do tej pory podziwiać można w chórze kościoła (il. 2).

Do podobnych wniosków skłania analiza strefy kapitelowej. Kapitele dla „niskiego kościoła” wykonane zostały w pierwszym trzydziestoleciu XIV wieku ${ }^{3} \mathrm{z}$ gipsu jastrychowego. Przygotowano je w dwóch wariantach technologicznych:

a) z przeważającym dodatkiem mielonej cegły,

b) z przeważającym dodatkiem węgla drzewnego.

Detale odlane zostały w kilku częściach, składających się na jeden kapitel idealnie okalający filar. Powierzchnia opracowana została wówczas bardzo starannie a formy architektoniczne precyzyjnie wyrzeźbione. Uwagę zwracają warsztatowe ślady, zachowane na górnych powierzchniach kapiteli wieńczących półfilary niskiego kościoła. Widnieją na nich ryty wykonane w mokrej zaprawie powtarzające kształt filara znajdującego się poniżej strefy kapitelowej. Pierwotnie na tych powierzchniach opierały się spływy sklepienne tzw. drugiego kościoła, usunięte podczas podwyższania sklepienia świątyni. Niewykluczone, że były to ryty wykonane przez kamieniarzy jako rysunki pomocnicze dla budowniczych (il. 3).

Przy podnoszeniu filarów podczas XV-wiecznej przebudowy kościoła, kapitele usunięto i wykorzystano wtórnie jako zwieńczenie wysokich filarów. Przy demontażu gzymsy uszkodzono i, co charakterystyczne, zamontowano w stanie zdewastowanym, nie siląc się na naprawy i rekonstrukcje. Rażące ubytki wypełniono m.in. kamieniami polnymi, które spełniły jednocześnie funkcję konsol. Uszkodzenia sporadycznie wyprowadzono zaprawą wapienno -piaskową bez dbałości o powtórzenie formy kapiteli, a całość zamalowano ujednolicającą pobiałą, wspólną dla sklepień i filarów (il. 4).

Podobną „nonszalancję warsztatową” można obserwować również w obrębie grupy konsol, których różnorodna forma i opracowanie malarskie świadczyć może o przypadkowości pracy murarzy oraz o chętnym wykorzystywaniu elementów, pochodzących „z odzysku”. Próbując usystematyzować materiał rzeźbiarski, konsole przynależne do XV-wiecznego

2 Inskrypcja na ścianie zachodniej datująca wznoszenie sklepień: Im Jare m IIIIc Im lxxiii am abende sente lorentz Ist dis Gewelbe Geslossen. (W roku 1473 w wigilię św. Wawrzyńca sklepienie to zostało ukończone. Tłum.: I. Brzostowska).

3 Datowanie budowy tzw. drugiego kościoła zaczerpnięto z artykułu Elżbiety Pileckiej, por. Elżbieta PILECKA Kościót pw. św. Jana Chrzciciela i św. Jana Ewangelisty w Toruniu w okresie średniowiecza jako wizualizacja świadomości społecznej, [w:] Dzieje i skarby kościoła Świętojańskiego w Toruniu, Materiały z konferencji przygotowanej przez Toruński Oddział Stowarzyszenia Historyków Sztuki w X rocznicę ustanowienia diecezji toruńskiej, 22-23 marca 2002, red. K. KLUCZWAJD, M. WOŹNIAK, Toruń 2002, s.119-176. Autorka wspiera się badaniami Arthura Semrau oraz Teresy Mroczko. 
wnętrza podzielono na trzy grupy utworzone pod względem materiału, z którego zostały wykonane. Są to konsole z piaskowca, z wapienia zbitego oraz z gipsu jastrychowego.

Konsole wykonane z piaskowca są najmniej liczną grupą, obejmującą zaledwie dwa elementy. Charakteryzują się wyobloną formą, zamkniętą rozbudowanym abakusem. Sprawiają wrażenie niewykończonych, przygotowanych do dalszej obróbki rzeźbiarskiej. Widnieją na nich ślady wcześniejszej polichromii, które dowodzą, że przed zamontowaniem w „wysokim kościele” zdobiły inne wnętrze. W XV-wiecznej farze Świętojańskiej zostały zamontowane z drobnymi uszkodzeniami i zamalowane pobiałą ujednolicającą całe wnętrze.

Druga grupa konsol to detale $\mathrm{z}$ wapienia zbitego - najatrakcyjniejszy pod względem artystycznym zespół wsporników, do którego należą bogato rozrzeźbione formy architektoniczne i floralne. Wśród nich jeden, ze względu na zawarte treści ikonograficzne i prezentowany warsztat rzeźbiarski zasługuje na szczególną uwagę. Przedstawione hybrydy antropo- i zoomorficzne rzeźbione są w swobodnych, zróżnicowanych pozach z dużą dbałością o szczegół i świadczą o wybitnych umiejętnościach rzeźbiarskich twórcy. Grupa zworników z wapienia jednoznacznie pochodzi z innego być może XIV - wiecznego wnętrza ${ }^{4}$. W „wysokim kościele”, podobnie jak pozostałe omówione detale, zostały zamontowane z dużą nonszalancją. Ubytków nie uzupełniono, a detal tak wysokiej klasy artystycznej zamontowano niestarannie, w miejscu zupełnie niewidocznym dla odwiedzających świątynię. Ponadto, stosując metodę tą samą dla wszystkich wtórnie wykorzystanych elementów, zamalowano je ujednolicającą pobiałą, czym spowodowano, że stały się jeszcze mniej czytelne (il. 6).

Ostatnia grupa - konsole z gipsu jastrychowego - to grupa o szerokim wachlarzu typologicznym, formalnym i warsztatowym. Znajdujemy tu: rozbudowane, atrakcyjne formy floralne, uproszczone formy architektoniczne a także detale rażąco bezkształtne. Większość z nich w fazie XV-wiecznej rozbudowy została zastosowana wtórnie, czego dowodzą ślady dekoracji z wcześniejszych ekspozycji oraz kształt, który nie odpowiada „dźwiganym” spływom sklepiennym. O beztrosce towarzyszącej dobieraniu detalu do ekspozycji niech świadczą zastosowane w roli wsporników fragmenty spływów sklepiennych pochodzące prawdopodobnie z tzw. drugiego kościoła (il. 5). Wszystkie elementy, pełniące funkcję wsporników, zamontowane zostały w sposób przypadkowy, niestaranny a na końcu pomalowane porządkującą pobiałą.

Wśród konsol z gipsu jastrychowego odnaleźć można kilka takich, które formą i dekoracją malarską sugerują, że zostały wykonane z przeznaczeniem do omawianego, XV-wiecznego wnętrza. Umieszczone są w dwóch przęsłach przywieżowych nawy północnej i południo$w^{5} j^{5}$. Wspólne dla nich są gabaryty odpowiadające spływom sklepiennym, pod którymi zostały zamontowane, dekoracje malarskie równoległe pod względem chronologicznym

4 Tadeusz JURKOWLANIEC, Jaki sens mają te śmieszne potworności?, „Rocznik Historii Sztuki”, t. 27, 1988, s. $55-58$.

5 Analiza nawarstwień (pobiał i warstw malarskich), oraz form architektonicznych (kształtu żeber i zworników) sugeruje, że są to części kościoła budowane wcześniej niż pozostałe partie korpusu. Możliwe zatem, iż wykonywane były przez inny warsztat rzemieślniczy. 
z dekoracją sklepień, na co wskazały badania stratygrafii warstw a także spójny pod względem artystycznym warsztat rzeźbiarski.

Elementem wystroju wysokiego kościoła, zasługującym na uwagę pod względem warsztatowym, są również zworniki. Tu także możemy mówić o niejednolitej koncepcji programowej. Przęsła przywieżowe nawy północnej i południowej zdobione są zwornikami architektonicznymi, zgodnymi pod względem koncepcyjnym z artykulacją sklepienia. Są to zworniki, wykonane w narzucie z zaprawy wapienno-piaskowej bezpośrednio na sklepieniu - okrągłe, płaskie, zdobione uproszczonymi formami płaskorzeźbionymi lub rytami (il. 7).

W całym niemal korpusie świątyni (z wyjątkiem przęsła drugiego od zachodu w nawie północnej), znajdują się drewniane zworniki dekoracyjne. Okrągłe, płaskie, podwieszone na długich $(\mathrm{ok} .50 \mathrm{~cm}$ ) metalowych bolcach, które umieszczono w otworach, powstałych u zbiegu żeber. Wykonano je z drewna, lokalnie przeklejonego płótnem. W mokrej, cienko roztartej zaprawie naniesiono ryt, wyznaczający rysunek dekoracji: gwiazdę wpisaną w okrąg. Gwiazdę wyzłocono, a tło pokryto błękitem i obwiedziono ugrową bordiurką wzdłuż zewnętrznej krawędzi zwornika ${ }^{6}$ (il. 8).

Trzecia grupa zworników to detale ze sztucznego kamienia. Prezentują różne formy i prawdopodobnie wyszły z innych warsztatów a przynajmniej spod różnych rąk rzeźbiarskich. Wszystkie umieszczone zostały w jednym wspomnianym wyżej przęśle: drugim od zachodu w nawie północnej. Cztery z nich to zworniki płaskie, dekorowane malowanymi herbami Polski, Torunia oraz gwiazdą. Formy rzeźbiarskie wykonane zostały starannie, tarcze herbowe pobielone pobiałą „mokre w mokre” i polichromowane na niedoschniętej pobiale. Kolejne cztery zworniki z tej grupy to detale o bardziej rozbudowanej formie, przypominającej stożek dekorowany płaskorzeźbionym motywem floralnym. Przy ich montażu obtłuczono ranty, tak by możliwe było zamontowanie pod wymurowanym wcześniej sklepieniem. Ostatni z omawianej grupy to zwornik usytuowany w kluczu sklepienia okrągły, płaski, ozdobiony reliefowym przedstawieniem Baranka Bożego, rzeźbionym w sposób uproszczony, wręcz naiwny. Różnice formalne pomiędzy omawianymi detalami sugerują, że zostały wykorzystane wtórnie, a ich pierwotnym przeznaczeniem było inne wnętrze. Tutaj - zgromadzone w jednym przęśle - stworzyły grupę barwną, ale prawdopodobnie przypadkową (il. 9).

Analizując warsztat murarski należy pochylić się również nad wyprawami tynkarskimi. Tynki „wysokiego kościoła” wykonane zostały z zapraw wapienno-piaskowych o zbliżonym składzie. Wyjątek stanowi tynk sklepienny, do którego dodano sierść zwierzęcą, służącą prawdopodobnie uelastycznieniu i poprawieniu przyczepności wypraw nakładanych na

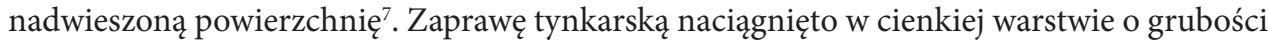
od kilku milimetrów do półtora centymetra. Tynki powtarzają wszelkie nierówności muru, czasem wręcz przechodzą w formę zacierki, spod której widoczny jest wątek ceglany. Ich

6 W XIX w. wykonano rekonstrukcję brakujących zworników. Przy wprowadzaniu kolorów zasugerowano się zmienioną pod wpływem działania czynników atmosferycznych kolorystyką oryginału. Gwiazdę wymalowano brązem („brudne” złoto) a tło zielenią (utleniony błękit).

7 Badania petrograficzne próbek zaprawy z katedry pw. św. Jana Chrzciciela i św. Jana Ewangelisty w Toruniu wykonał dr Wojciech Bartz, archiwum firmy RESTAURO w Toruniu. 
powierzchnię opracowano głównie pacą murarską, jednak zdarzają się miejsca - zwłaszcza w glifach okiennych - gdzie tynk był rozprowadzony pędzlem a potem zatarty małą kielnią, która pozostawiła charakterystyczne, nierównomierne wygładzenia (il. 10).

W zdecydowanej większości przypadków, na jeszcze nie do końca związane tynki naniesiono pobiałę (świadczy o tym stopień związania pobiały z podłożem). Pracowano z dużą swobodą, malując z rozmachem w różnych kierunkach. Pobiałę miejscami nałożono grubo, pozostawiając widoczny dukt pędzla a czasami tak cienko, że widoczne jest uziarnienie zaprawy, na której leży.

Interesująca jest kolejność, w jakiej nakładano wyprawy tynkarskie na ściany podwyższonej świątyni. W toku prac konserwatorskich - na podstawie stratygrafii warstw i analizy porównawczej - ustalono, że był to proces wieloetapowy, przy czym inaczej przebiegał na ścianach północnej i południowej, a inaczej na ścianach zachodnich i przywieżowych.

Na przykładzie ściany południowej stwierdzono, że ściany „boczne” tynkowano w następującej kolejności: jako pierwsze przykryto powierzchnie glifów okiennych, następnie płaszczyznę ściany na wysokości kaplic (do ok. 1 metra poniżej linii parapetów). Później nałożono tynki na sklepienie i ściany poniżej aż do wysokości nasady sklepień, by na koniec przykryć powierzchnię od nasady sklepień do parapetów (il. 11). W ten sposób na szerokości ok. $1 \mathrm{~m}$ pod linią parapetów pozostał nieotynkowany pas, powstały prawdopodobnie ze względu na konstrukcję rusztowań lub inne względy techniczne. Tam, tynki nałożono na końcu, bardzo niestarannie, jakby w pośpiechu, często tylko bieląc cegły. Tą samą pobiałą pomalowano wcześniej naciągnięty tynk poniżej. Na nią naniesiono dekorację nad arkadami kaplic, tożsamą pod względem chronologicznym z dekoracją sklepień. Taka wieloetapowość prac tynkarskich świadczy prawdopodobnie o długotrwałym ich przebiegu i skłania do pytań, o konkretne powody powyżej opisanej kolejności ich realizacji.

Na przywieżowych i zachodnich ścianach naw bocznych tynki, w pierwszym etapie, nałożone zostały od poziomu posadzki do linii parapetów. Niewiele poniżej ich górnej krawędzi znajdują się otwory po belkach stropowych, które sugerują, że przez pewien czas przęsło przywieżowe przykryte było stropem. W następnej kolejności nałożono tynki od linii parapetów w górę do podstawy sklepień. Całą powierzchnię ścian przykryto ujednolicającą pobiałą ${ }^{8}$.

Program malarski piętnastowiecznego wnętrza kościoła św. Jana jest dość jednorodny i koncentruje się głównie na dekoracji sklepień. Odnalezione na sklepieniu korpusu motywy malarskie są z całą pewnością pierwszą dekoracją wnętrza wysokiej świątyni i powstały niedługo po przesklepieniu kościoła. Świadczy o tym czysta cegła, którą wymurowano sklepienie a odsłonięta w toku prac spod piętnastowiecznych tynków, idealnie czysta pobiała pod polichromią a także ryty wykonywane w mokrej pobiale stanowiące rysunek pomocniczy dla malarzy. Program malarski korpusu „wysokiej świątyni” obejmuje motyw trójliścia wiedzionego wzdłuż linii żeber, urozmaicony w kluczach sklepiennych i w niektórych narożni-

8 Ciekawym reliktem warsztatowym jest ryt odnaleziony na wysokości ok. $1,5 \mathrm{~m}$ nad poziomem posadzki na ścianie przywieżowej nawy południowej. Przedstawia maswerk, kreślony cyrklem o średnicy nie większej niż $50 \mathrm{~cm}$. Został on wyrysowany z niebywałą precyzją i szczegółowością wyprowadzonych kształtów. Mógł być „wprawką" lub szkicem planowanej dekoracji świątyni. 
kach wysklepek dekoracją floralną o bardzo bogatych formach. Wyjątkiem są przęsła przywieżowe oraz podłucze niszy wieży. W przęśle przywieżowym nawy południowej odnajdujemy powtarzający się motyw lilijek, wiedzionych wzdłuż żeber. Żebra malowane są naprzemiennie czerwienią i zielenią w sposób imitujący wątek ceglany. Przęsło przywieżowe nawy północnej zdobi niebieska wić roślinna, prowadzona po wysklepkach i po żebrach (il. 7). Z analizy pobiał wynika, iż w przęsłach przywieżowych program tynkarsko-malarski wykonano wcześniej, niż w korpusie. Może to tłumaczyć rozbieżności formalne dekoracji, które mają swoje odzwierciedlenie również w programie architektonicznym, a konkretnie w kształcie żeber i zworników sklepiennych. Powierzchnia podłucza niszy wieży i częściowo ścian poniżej przykryta jest „mozaikową”, wielobarwną dekoracją malarską.

Obrazu całości dopełniają dekoracje kaplic i ścian. Sklepienia kaplic zdobione są powtarzającym się motywem czerwonego i zielonego fleurona, malowanego wzdłuż żeber. Żebra we wklęsce i na grzbiecie podkreślone są czerwonym paskiem ${ }^{9}$. Łuki ponad wejściami do kaplic zdobiono różnorodnymi motywami floralnymi. Na ścianach najważniejszymi kompozycjami malarskimi były: przedstawienie Chrystusa Boleściwego (ściana zachodnia nawy południowej), wizerunek św. Weroniki (ściana wschodnia nawy południowej), inskrypcja datująca wybudowanie sklepień (ściana zachodnia nawy północnej) oraz kilka niewielkich herbów lub inskrypcji. Całość komponuje się spójnie, na co wpływ ma m.in. wspólna paleta kolorów. Dotychczas zidentyfikowane pigmenty XV-wiecznego warsztatu malarskiego, to czerwień żelazowa, czerń roślinna, azuryt i malachit ${ }^{10}$.

Przy analizie dekoracji sklepień korpusu uwagę przykuwa swoboda w tworzeniu nowych form roślinnych (kwiatowych, warzywnych), usytuowanych w narożnikach poszczególnych wysklepek, głównie w okolicach kluczy sklepiennych. Ornamenty budowane są najczęściej z kilku powtarzających się elementów, które za każdym razem tworzą nową formę. Podstawowe komponenty wielokrotnie zostały wykrzywione lub powiększone, dzięki czemu stworzyły wzór różnorodny i barwny (il. 9, 12). Niektóre formy wymalowano starannie, inne zupełnie nieudolnie, co sugeruje udział przynajmniej kilku malarzy w tworzeniu dekoracji sklepień. Zauważalne są różnice tematyczne w obrębie poszczególnych przęseł, wynikające być może z indywidualnego dla każdego zespołu stosowania ulubionych kształtów i sposobu ich malowania. Interesującym odkryciem są pozostałości próbnych rozmalowań, wprawek, które zaraz po wymalowaniu i zweryfikowaniu przykryto pobiałą, na którą naniesiono właściwą dekorację malarską. Są wśród nich: polichromia przykryta wizerunkiem św. Weroniki (ściana wschodnia nawy południowej), rytm trefli pod ostatecznie wprowadzonymi lilijkami (przęsło przywieżowe w nawie południowej, il. 8), szkic w glifie okiennym (nawa południowa) i wiele podobnych, udokumentowanych i zamieszczonych w dokumentacji powykonawczej.

Przedstawiony tu obraz świątyni wznoszonej w XV wieku skłania do postawienia wielu pytań. Duża niejednorodność koncepcyjna i warsztatowa świadczyć może o konieczności

9 Konsultacje z p. Krzysztofem Owsianym.

10 Wyniki badań próbek polichromii z filarów międzynawowych i sklepienia nawy południowej katedry pw. św. św. Janów w Toruniu, Polskie Pracownie Konserwacji Zabytków, Laboratorium Naukowo-Badawcze w Toruniu, archiwum firmy RESTAURO w Toruniu. 
podejmowania przez budowniczych szybkich, często niezgodnych z wcześniejszymi założeniami decyzji. Na ile taki stan rzeczy wynikać mógł z trwających zmagań wojennych, zakończonych pokojem toruńskim w 1466 roku? Jaki wpływ sytuacja polityczna miała na możliwości finansowe i priorytety inwestycyjne parafii i miasta?...

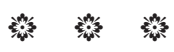

\section{$15^{\text {th }}$ century craftsmen's and artists' workshop of buildersof the church of St. John the Baptist and St. John the Evangelist in Toruń}

The schedule of conservation works in the church of St. Johns led by the RESTAURO company between 2010 and 2013 assumed the restoration of the cathedral's decorations from the second half of the $15^{\text {th }}$ century, when the church got its current form.

In the course of the works a picture of the elevated temple decorated in a chaotic, even hasty way emerged. It has been mainly proved by the analysis of masonry and sculpture techniques applied to the vaults of the cathedral's main nave that had been under construction during the second half of the $15^{\text {th }}$ century.

Vault ribs often break geometric rules. Keystones and places where ribs meet each other are made in a sloppy way, far from standards set by the $14^{\text {th }}$ century builders. Capitals removed from the lower church's pillars, for which they had been built in the first half of the $14^{\text {th }}$ century, were reused in the high interior of the church. During the dismantling works cornices had been spoilt and, what is quite distinctive, mounted as devastated not bothering of repair and reconstruction. Possible glaring cavities were filled by field stones that also served as corbels. The whole was painted with standardizing lime wash - the same for vaults, piers, and walls. Similar workshop nonchalance can be observed for other corbels, which constitute much diversified sculpture group. Plenty of forms and various ways of their finishing means the work were coincidental and materials were often reused. Corbels are made of several materials, come from various sculpture workshops and bear marks of former displays. In the $15^{\text {th }}$ century interior they were installed carelessly, without attention paid to matching forms of details of the beginning of vaults they carried. The cavities were not refilled and the whole was lime-washed. Keystones represent non-standardized policy concept as well. Only the bays on the northern and southern side of the tower are decorated with keystones that are indisputably coherent with the architectural structure of the vault. The other ones seems to be produced in a hurry (wooden keystones hung on metal pins) or reused (a group of keystones made of screed plaster, placed in the northern aisle, which differ formally and in terms of workmanship).

The painting program of the main nave of the $15^{\text {th }}$ century temple presents itself as the most coherent part. It focuses mostly on decorations of the vaults. It consists mostly of a three-leaf pattern led along arch ribs, enriched by floral ornaments. Some forms are painted nattily, while others show absolute bogosity, which suggests that at least a few painters representing different skill levels took part in creating the ornaments. 
The workshop of builders working during the second half of the $15^{\text {th }}$ century surprises with its nonchalance and pushes into asking questions of influence of the political situation of the city after the peace treaty of Torun on financial capabilities and investment priorities of the parish. 


\section{SPIS ILUSTRACJI}

1. Toruń, kościół pw. św. Jana Chrzciciela i św. Jana Ewangelisty. Filar nawy południowej, fragment muru z widocznym opracowaniem murarskim z XIV w. - dolne partie, i XV w. - górne partie, fot. I. Brzostowska.

2. Toruń, kościół pw. św. Jana Chrzciciela i św. Jana Ewangelisty. Sklepienie nawy południowej, warsztat murarski z II poł. XV w. - niestaranne łączenie żeber sklepiennych, fot. I. Brzostowska.

3. Toruń, kościół pw. św. Jana Chrzciciela i św. Jana Ewangelisty. Kapitel półfilaru nawy północnej, XIV-wieczny warsztat odlewniczy - widoczny ryt wyrysowany w mokrej pobiale na górnej powierzchni kapitelu, fot. I. Brzostowska.

4. Toruń, kościół pw. św. Jana Chrzciciela i św. Jana Ewangelisty. Filar nawy północnej, warsztat murarski z II poł. XV w. - sposób opracowania strefy kapitelowej, fot. I. Brzostowska.

5. Toruń, kościół pw. św. Jana Chrzciciela i św. Jana Ewangelisty. Spływ sklepienny nawy południowej, warsztat murarski z II poł XV w. - konsola z wykorzystanego wtórnie fragmentu spływu sklepiennego z czasu niskiego kościoła, fot. I. Brzostowska.

6. Toruń, kościół pw. św. Jana Chrzciciela i św. Jana Ewangelisty. Filar nawy południowej, warsztat murarski z I poł. XV w. - wtórnie wykorzystana konsola z wapienia zbitego o wyjątkowych walorach artystycznych i ikonograficznych, fot. I. Brzostowska.

7. Toruń, kościół pw. św. Jana Chrzciciela i św. Jana Ewangelisty. Sklepienie nawy północnej, przęsło przywieżowe, warsztat murarski i malarski z II poł. XV w., fot. I. Brzostowska.

8. Toruń, kościół pw. św. Jana Chrzciciela i św. Jana Ewangelisty. Sklepienie nawy południowej, warsztat malarski z II poł. XV w., fot. I. Brzostowska.

9. Toruń, kościół pw. św. Jana Chrzciciela i św. Jana Ewangelisty. Sklepienie nawy północnej, drugie przęsło od zach., warsztat murarski i malarski z II poł. XV w., fot. K. Daniel.

10. Toruń, kościół pw. św. Jana Chrzciciela i św. Jana Ewangelisty. Glif okna nawy południowej, XV -wieczny warsztat murarski - sposób opracowania powierzchni tynku, fot. I. Brzostowska.

11. Toruń, kościół pw. św. Jana Chrzciciela i św. Jana Ewangelisty. Ściana południowa, XV-wieczny warsztat murarski - kolejność nakładania tynków w XV w., fot. I. Brzostowska, opracowanie graf. K. Daniel.

12. Toruń, kościół pw. św. Jana Chrzciciela i św. Jana Ewangelisty. Sklepienie nawy południowej, pierwsze przęsło od wsch., warsztat malarski, fot. I. Brzostowska. 


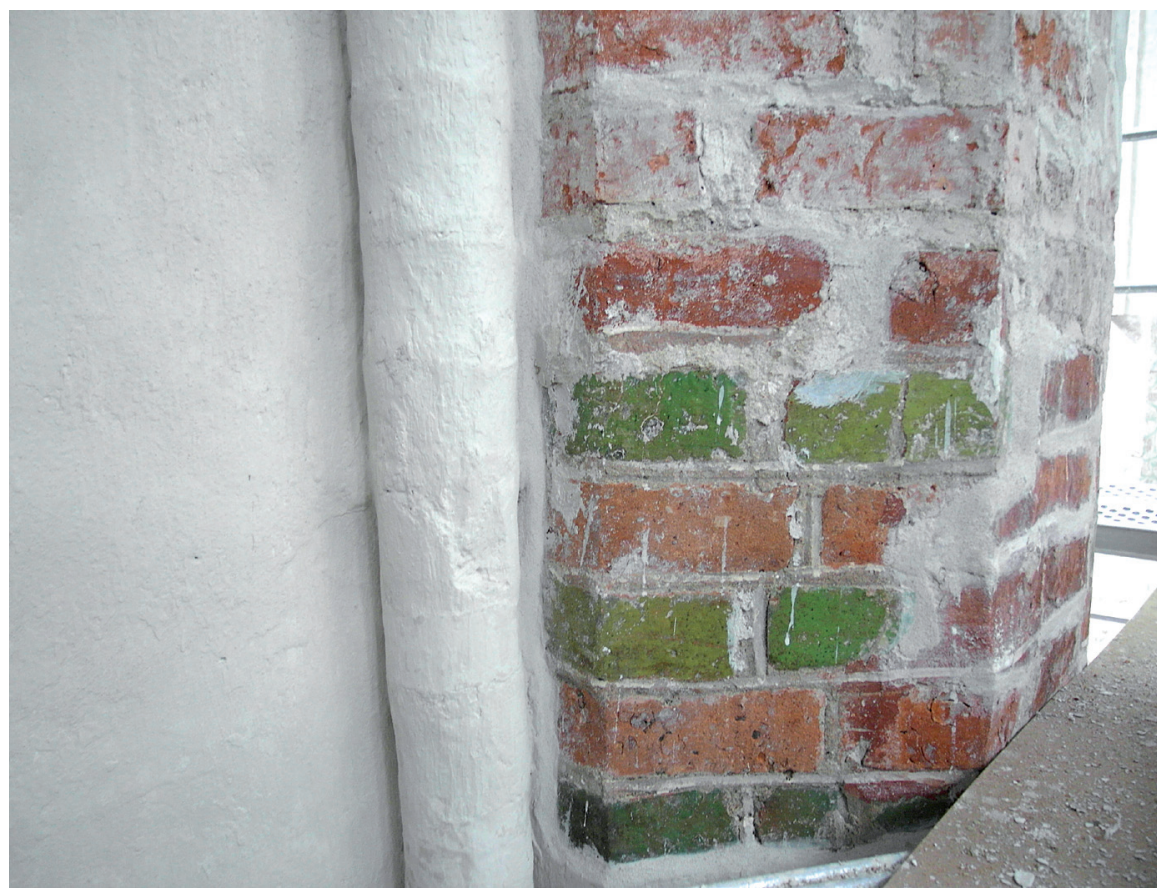

Il. 1 Filar nawy południowej, fragment muru z widocznym opracowaniem murarskim z XIV w. - dolne partie, i XV w. - górne partie, fot. I. Brzostowska

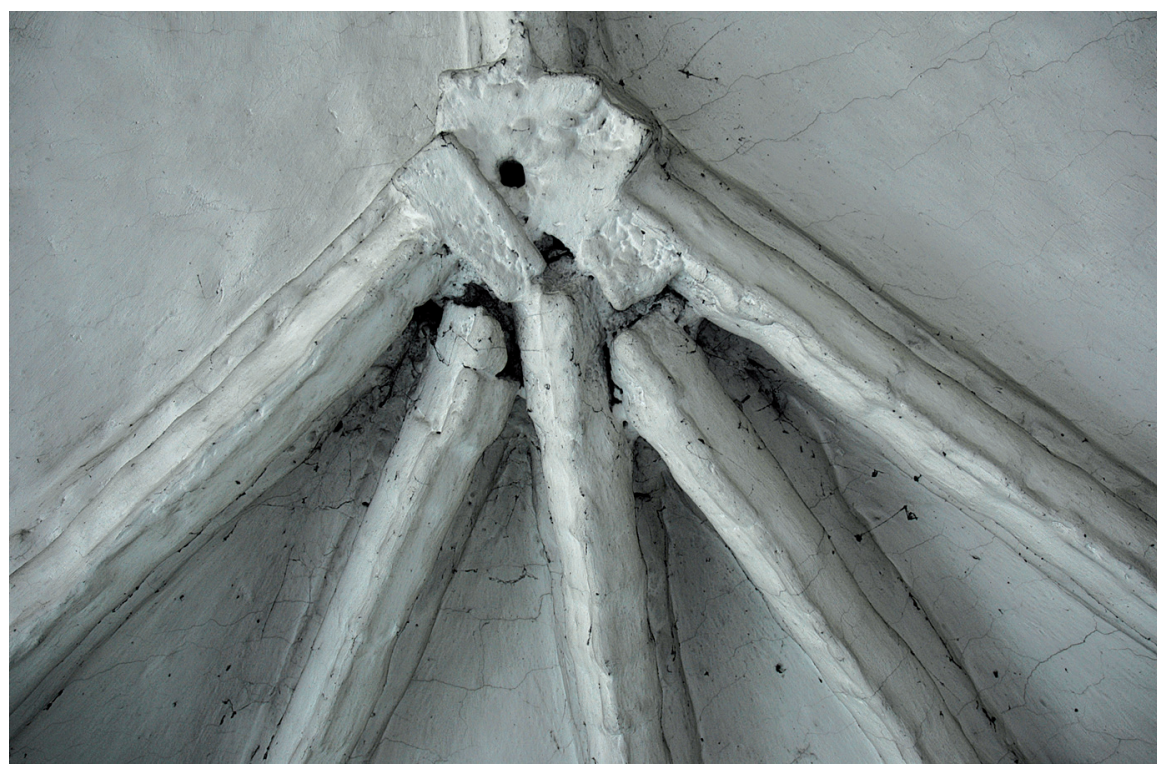

Il.2 Sklepienie nawy południowej, warsztat murarski z II poł. XV w. - niestaranne łączenie żeber sklepiennych, fot. I. Brzostowska 


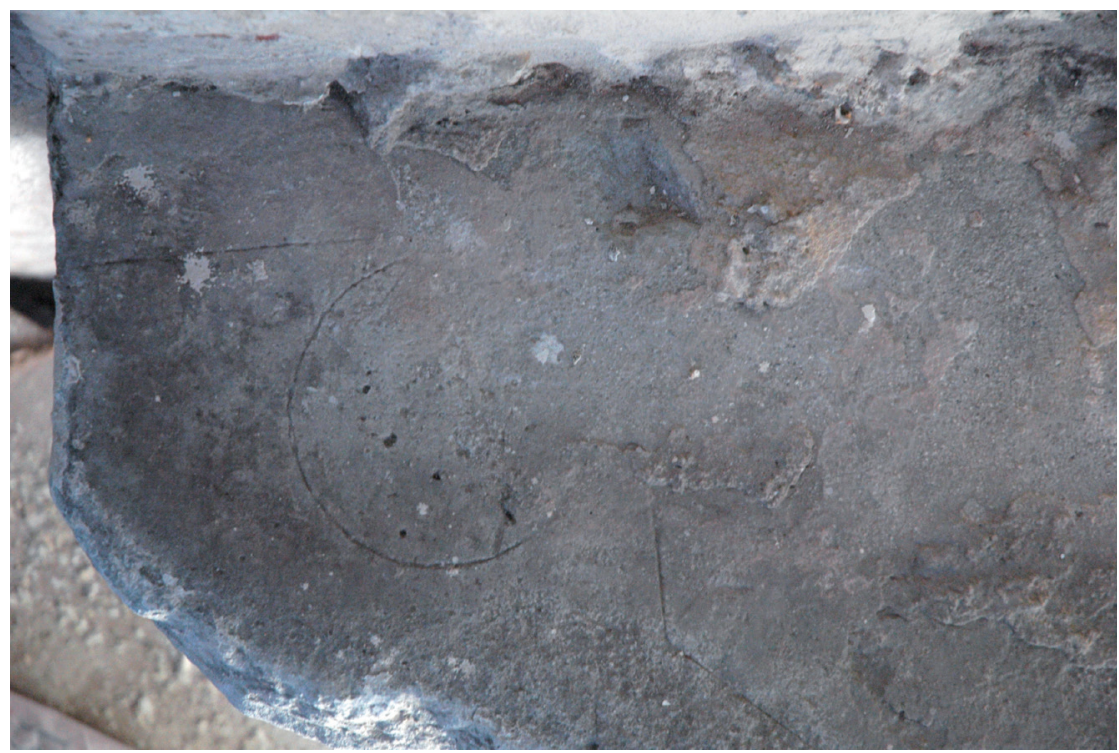

Il. 3 Toruń, kościół pw. św. Jana Chrzciciela i św. Jana Ewangelisty. Kapitel półfilaru nawy północnej, XIV-wieczny warsztat odlewniczy - widoczny ryt wyrysowany w mokrej pobiale na górnej powierzchni kapitelu, fot. I. Brzostowska

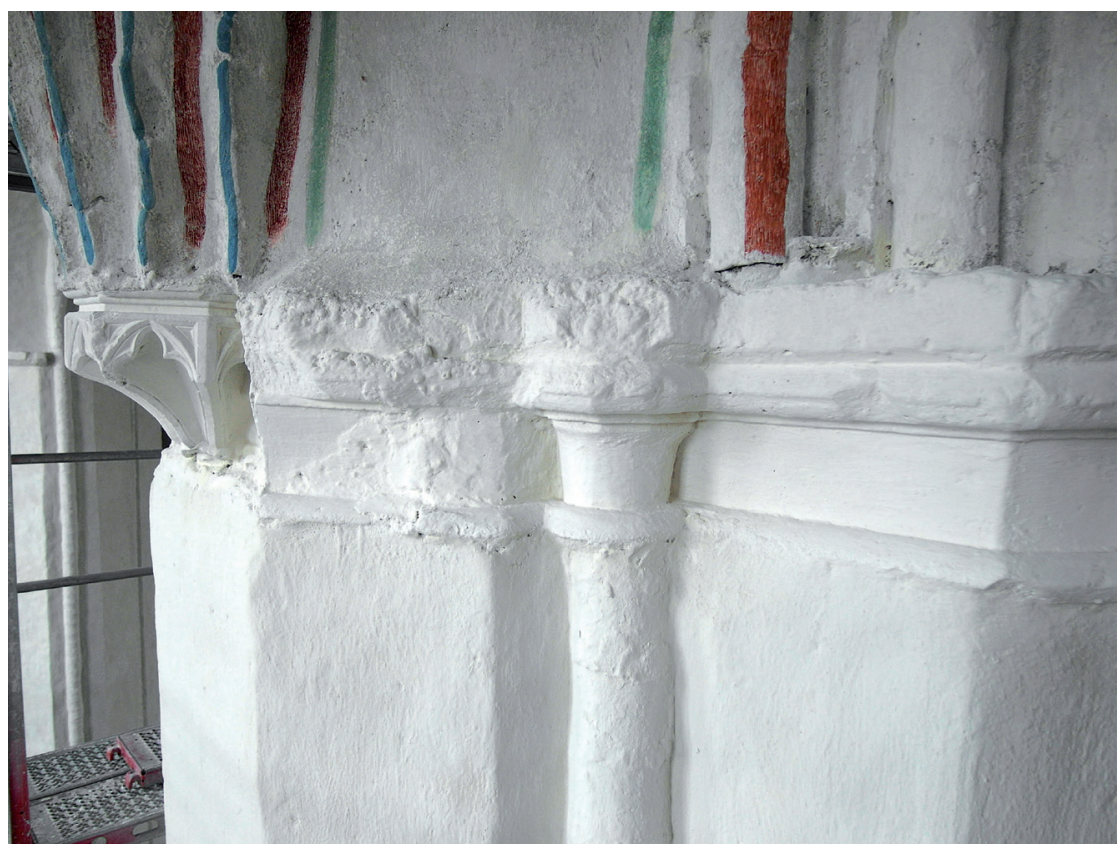

Il. 4 Toruń, kościół pw. św. Jana Chrzciciela i św. Jana Ewangelisty. Filar nawy północnej, warsztat murarski z II poł. XV w. - sposób opracowania strefy kapitelowej, fot. I. Brzostowska 


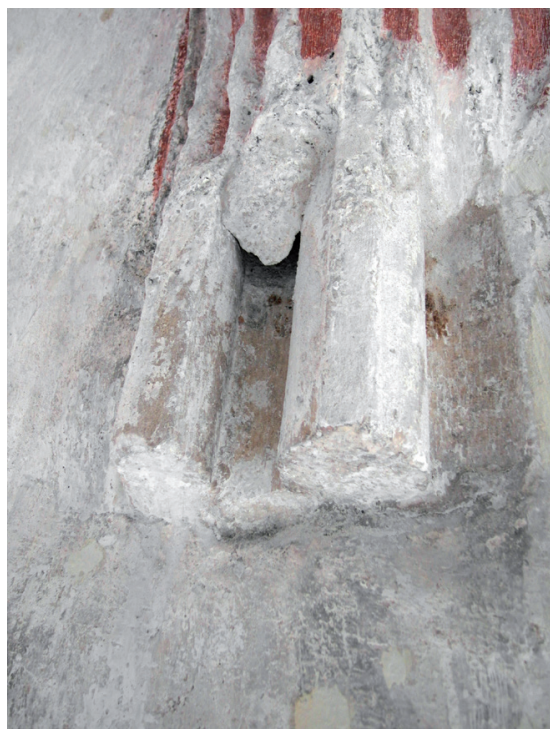

Il. 5 Toruń, kościół pw. św. Jana Chrzciciela i św. Jana Ewangelisty. Spływ sklepienny nawy południowej, warsztat murarski z II poł XV w. - konsola z wykorzystanego wtórnie fragmentu spływu sklepiennego z czasu niskiego kościoła, fot. I. Brzostowska

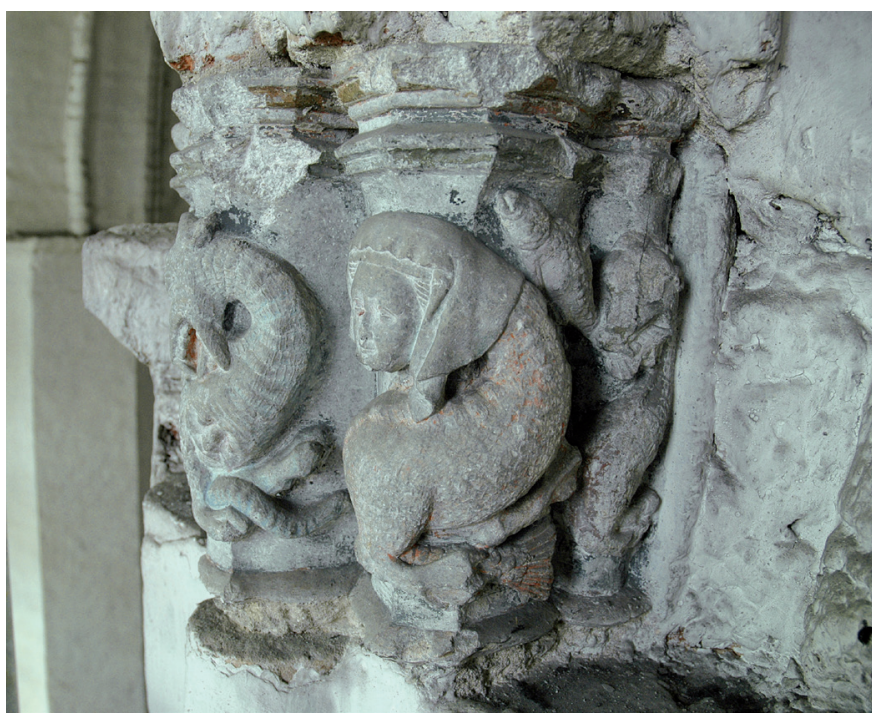

Il. 6 Toruń, kościół pw. św. Jana Chrzciciela i św. Jana Ewangelisty. Filar nawy południowej, warsztat murarski z I poł. XV w. - wtórnie wykorzystana konsola $\mathrm{z}$ wapienia zbitego o wyjątkowych walorach artystycznych i ikonograficznych, fot. I. Brzostowska 


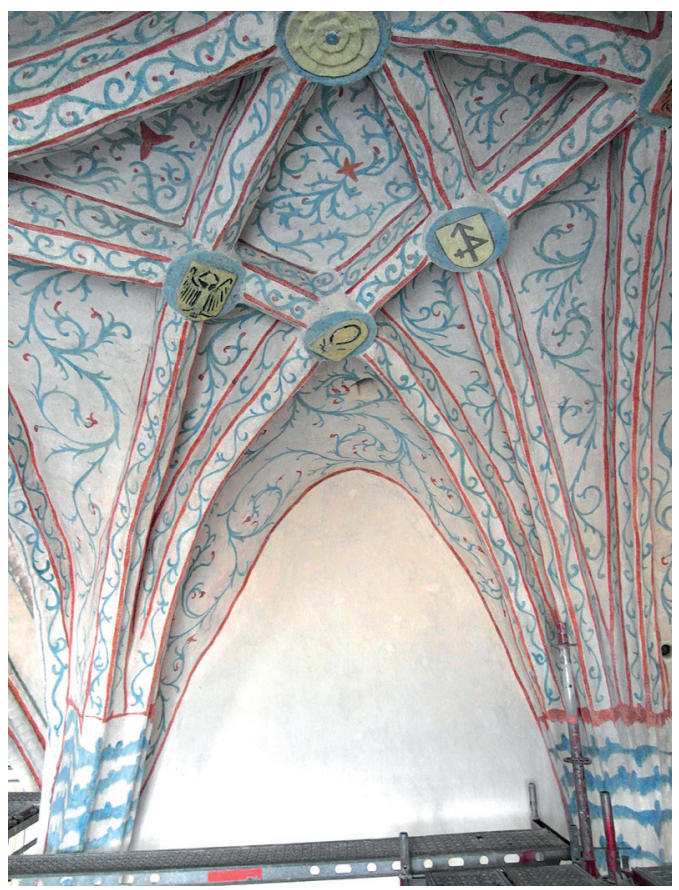

Il. 7 Toruń, kościół pw. św. Jana Chrzciciela i św. Jana Ewangelisty. Sklepienie nawy północnej, przęsło przywieżowe, warsztat murarski i malarski z II poł. XV w., fot. I. Brzostowska

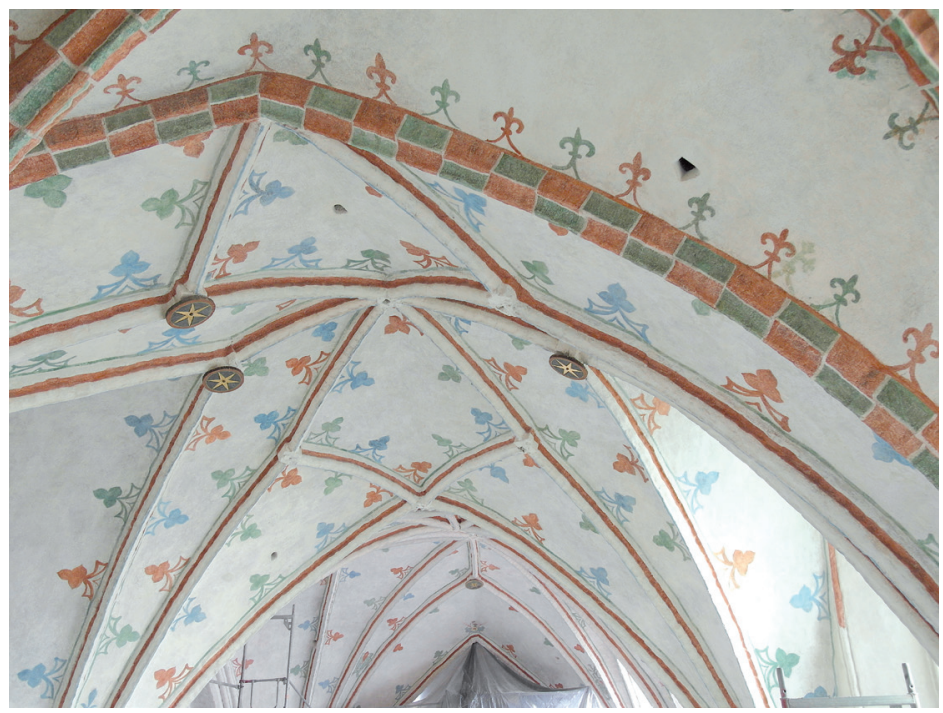

Il. 8 Toruń, kościół pw. św. Jana Chrzciciela i św. Jana Ewangelisty. Sklepienie nawy południowej, warsztat malarski z II poł. XV w., fot. I. Brzostowska 


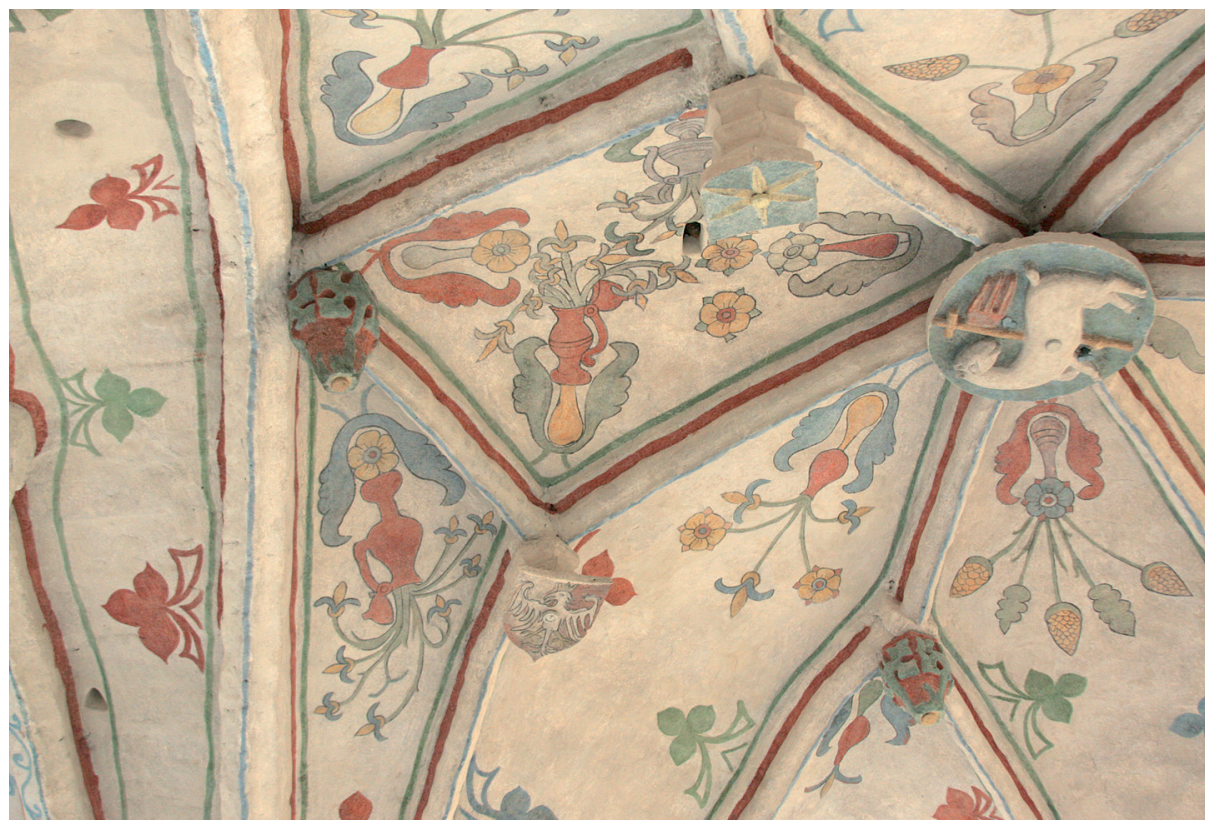

Il. 9 Toruń, kościół pw. św. Jana Chrzciciela i św. Jana Ewangelisty. Sklepienie nawy północnej, drugie przęsło od zach., warsztat murarski i malarski z II poł. XV w., fot. K. Daniel

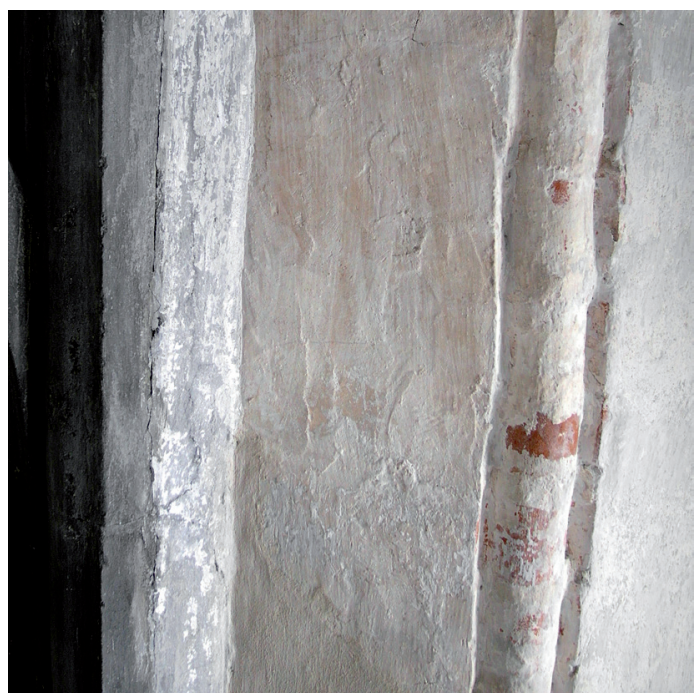

Il. 10 Toruń, kościół pw. św. Jana Chrzciciela i św. Jana Ewangelisty. Glif okna nawy południowej, XV-wieczny warsztat murarski - sposób opracowania powierzchni tynku, fot. I. Brzostowska 


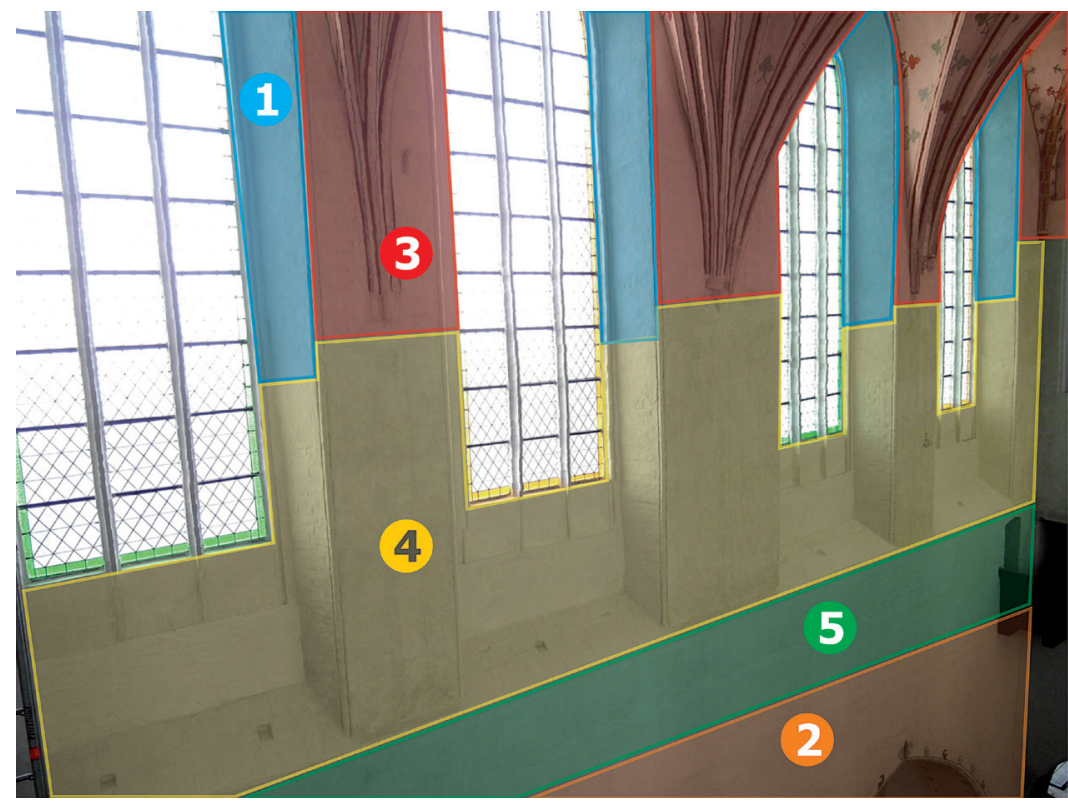

Il. 11 Toruń, kościół pw. św. Jana Chrzciciela i św. Jana Ewangelisty. Ściana południowa, XV-wieczny warsztat murarski - kolejność nakładania tynków w XV w., fot. I. Brzostowska, opracowanie graf. K. Daniel

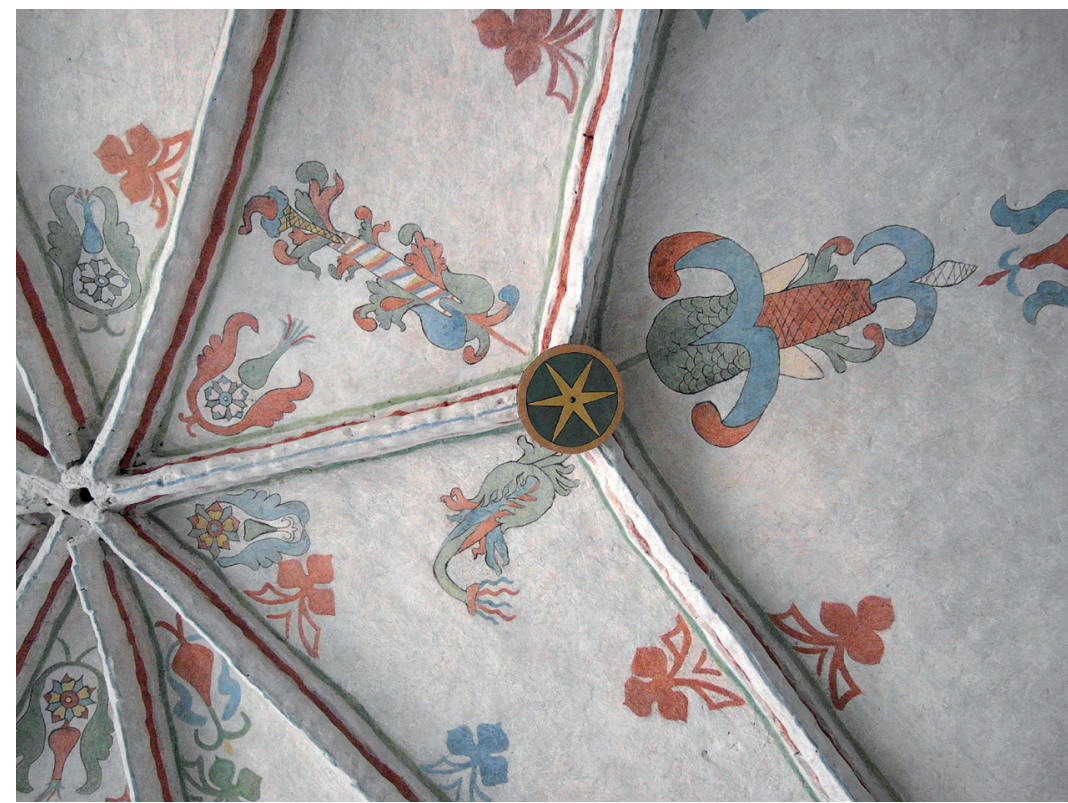

Il. 12 Toruń, kościół pw. św. Jana Chrzciciela i św. Jana Ewangelisty. Sklepienie nawy południowej, pierwsze przęsło od wsch., warsztat malarski, fot. I. Brzostowska 